\title{
INTERNATIONAL CORRESPONDENTS IN SPAIN FACING GOVERNMENT AND INFORMATION SOURCES. EVALUATION OF PROBLEMS BY ANALYTIC HIERARCHY PROCESS (AHP)
}

\author{
Los corresponsales internacionales en España ante \\ el Gobierno y las fuentes: evaluación de problemas \\ mediante proceso de análisis jerárquico (PAJ)
}

Teodoro-Adolfo León-Gross, Agustín Rivera-Hernández and Myriam Redondo-Escudero

Nota: Este artículo se puede leer en español en:

http://www.elprofesionaldelainformacion.com/contenidos/2018/jul/10_esp.pdf
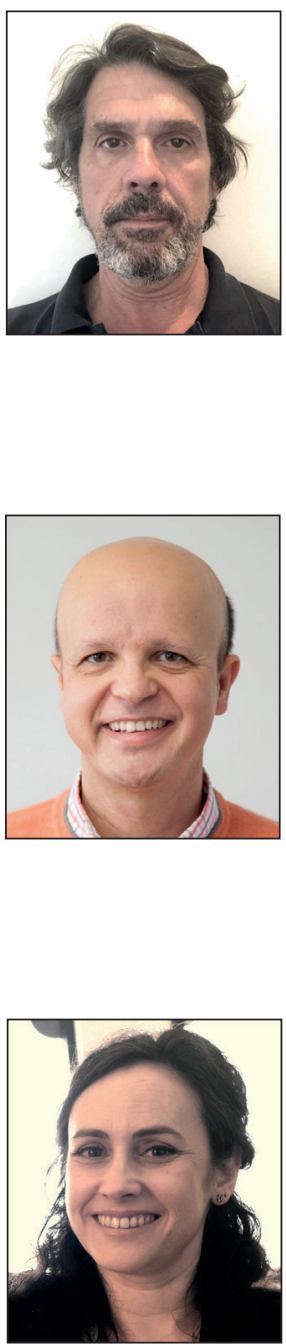

Teodoro-Adolfo León-Gross is a journalist, philologist, and holds a doctorate in Journalism; currently a tenured professor at the University of Málaga. Professor León-Gross is a columnist for El país; previously he has written for El mundo, Vocento, and the Andalusian edition of Diario 16, which he began his last year as a student. He is a commentator for the program Hoy por hoy of Cadena SER; director of the Manuel Alcántara Chair; and author of academic essays such as Singular feminine article, Ten columnists for the History of Literature, The weak journalism, The daily press in the EU, and The opinion article. He has been an analyst for Fundesco's annual reports on the media system and the Association of European Journalists for the forums of Ibero-American summits of heads of State. http://orcid.org/0000-0001-9281-0980

Universidad de Málaga, Facultad de Ciencias de la Comunicación, Departamento de Periodismo León Tolstoi, s/n. 29010 Málaga, Spain t.leongross@gmail.com

Agustín Rivera-Hernández is an associate professor at the Faculty of Communication Sciences of the University of Málaga; accredited by Aneca as an assistant professor doctor. He has participated in national research projects and in a dozen national and international conferences. He has also published articles of scientific impact in the field of Journalism. In the professional field he has 25 years of experience and has worked in Diario 16, El mundo (where he was a correspondent in Tokyo and special correspondent in 14 countries), and El confidencial, where he has been a delegate in Andalusia since January 2009.

http://orcid.org/0000-0003-3100-3610

Universidad de Málaga, Facultad de Ciencias de la Comunicación, Departamento de Periodismo León Tolstoi, s/n. 29010 Málaga, Spain agustinrivera@uma.es

Myriam Redondo-Escudero is a journalist and teacher. She specializes in the triangle that links digital communication, international reporting, and international relations; paying special attention to the virtual practice of correspondents and anti-misinformation technologies. She maintains the blog globograma.com and the debate initiative tertuliainfinita.com. She holds a PhD in International Relations; a Master's Degree in Politics, Culture, and European Society; and she is an advanced technician in Obtaining Information with Open Sources (Osint). She teaches International Relations at the Complutense University of Madrid. She collaborates with media such as Cuadernos de periodistas, Revista 5W, and Eldiario.es.

http://www.globograma.es

https://tertuliainfinita.com

http://orcid.org/0000-0001-9865-5651

Universidad Complutense de Madrid, Facultad de Ciencias de la Información Avda. Complutense, s/n. 28040 Madrid, Spain myriamre@ucm.es 


\begin{abstract}
Correspondents have faced significant changes in the professional model of journalism and the deterioration of the profession due to the effects of the economic crisis in the journalism sector. This article proposes an approach to this reality in Spain, and does so by trying to determine what specific factors make the tasks of correspondents more difficult within the general context of the structural weakening of journalism. The methodology Analytic Hierarchy Process (AHP) is used for this purpose. This methodology is based on the idea that the complexity inherent to an evaluative decision in which multiple factors intertwine can be resolved by quantitatively ranking them, which allows identifying what is truly influential. In this study, a panel of correspondents was interviewed with open questions about hinderances to their work, next their answers were turned into a survey which was administered to the same panel. This led us to determine the relative weight of four challenges: 1 . The lack of collaboration by the Government with correspondents; 2 . The difficulty in accessing sources; 3 . The agenda setting due to the loss of status of correspondents; 4 . The clash with Spanish culture.
\end{abstract}

\title{
Keywords
}

Correspondents; Spain; AHP; Analytic hierarchy process; International media; International journalism.

\section{Resumen}

Las corresponsalías se enfrentan a cambios significativos en el modelo profesional del periodismo y a un deterioro profesional por los efectos de la crisis económica en el sector. El presente artículo propone una aproximación a su realidad en España y lo hace tratando de determinar qué factores específicos dificultan más la tarea de los corresponsales destinados en este país dentro del contexto general de debilitamiento estructural del periodismo. Para ello se ha utilizado la metodología Analytic Hierarchy Process (AHP), en castellano conocida como PAJ (Proceso de Análisis Jerárquico). Dicha metodología parte de la idea de que la complejidad inherente a una decisión valorativa en la que intervienen múltiples factores se puede resolver jerarquizando cuantitativamente estos últimos, lo que permite objetivar qué es lo verdaderamente influyente. Primero se entrevistó a un panel de corresponsales con preguntas abiertas sobre aquello que entorpece su trabajo, y posteriormente sus respuestas se completaron con una encuesta directa realizada al mismo panel sobre la misma cuestión. Ello lleva a determinar el peso relativo de cuatro aspectos en su actividad: 1.- La falta de colaboración del Gobierno con las corresponsalías. 2.- La dificultad para acceder a las fuentes. 3.- La construcción de la agenda por la pérdida de entidad de las corresponsalías. 4.- El choque con la sociología española.

\section{Palabras clave}

Corresponsales; España; AHP; Proceso de Análisis Jerárquico; PAJ; Medios internacionales; Periodismo internacional.

León-Gross, Teodoro-Adolfo; Rivera-Hernández, Agustín; Redondo-Escudero, Myriam (2018). “International correspondents in Spain facing Government and information sources. Evaluation of problems by analytic hierarchy process (AHP)". El profesional de la información, v. 27, n. 4, pp. 813-821.

https://doi.org/10.3145/epi.2018.jul.10

\section{State of the situation: deterioration of the correspondent's role}

International correspondents represent an essential figure in the tradition of twentieth-century journalism. They maintain the values associated with the social responsibility of the press and their role has evolved with the impact of new technologies (Belair-Gagnon; Agur; Frisch, 2016). Johan Galtung, in the prologue to Mapping foreign correspondence in Europe (Galtung, 2014), a comprehensive study of foreign correspondents in 27 European countries, details how these accredited journalists fulfill a necessary function and provide a "unique source of information on the relevant world" (Galtung, 2014, p. XX). Hamelink (2014) expands on a complementary idea that journalism is able to reduce the pressure on speed to maintain quality. Technological developments and so-called "citizen journalism", channeled mainly through social media, produces news with high instantaneity, calling into question the role of correspondents (Archetti, 2012).

The crisis of the press, together with the international economic crisis that began in 2008 , has reduced the number and organizational means of correspondents. Over the past decade the annual reports of the journalistic profession, published by the Press Association of Madrid, has highlighted how the media has cut costs, something that had become noticeable a few years prior:

"they send fewer journalists to important events, covering information more and more with agency notes and copying from the internet" (Haubrich, 2005).

Sahagún insists that this is not just a reduction in costs, but also the disappearance of the correspondent's role, in Cuadernos de periodistas:

"The economic difficulties have forced the media to cut the international information budget and, to many of them, to reduce correspondents. As important or more than the number of correspondents is the use made of their presence and cost in a completely different information map. With exceptions, they renounce the essence of the figure of the correspondent: knowledge of the place, own sources, a better analysis and capacity to contextualize" (Sahagún, 2013, p. 17).

All this takes place in an information ecosystem where the 
internet has transformed the routines of the production of international news (Redondo, 2005; 2007) and has led the correspondents to carry out many more "desk" tasks than in previous years: searching, filtering, and managing of new digital sources (Sahagún, 2004; Nieman Foundation, 2010; Belair-Gagnon; Agur; Frisch, 2016); verification of user-generated content; and even publication in new multimedia formats. The dimension of the sources is particularly important, since the Internet allows a priori access to truly alternative voices - with little political, social, and economic relevance so far- in front of the usual spokespersons (organized and relevant) to whom the media came to get information. On the one hand, these new sources do not have the credibility or prestige of traditional sources, but they are fresh and fast; on the other, the journalist is no longer the only one capable of generating information and confronts a new competitor (Sambrook, 2010).

If the effect of the economic crisis has been very hard on the Spanish media, it has also translated into a reduction in the number of correspondents in Spain. Ramón Salaverría is the author of the most complete and updated study on the situation of foreign correspondents in the country (Salaverría, 2014). This investigation, from 2012, counted 258 correspondents accredited in Spain and distributed among a total of 202 media outlets: 89 newspapers, 49 radio and/ or television channels, 40 news agencies, and 24 magazines. Salaverría compares those figures with those of five years earlier, in 2008. His study concludes that the number of international media accredited in Spain had fallen by $14 \%$ in that period, especially in the audiovisual media. In 2008 there were 235 international media with at least one correspondent in our country: 92 newspapers, 64 radio and television channels, 43 news agencies, and 36 magazines.

Correspondents have been impacted by the change in model, while also adapting to the media difficulties and culture in each country. Walter Haubrich, correspondent of the Frankfurter Allgemeine Zeitung (FAZ) in Madrid for almost 40 years, a leading and decisive figure during the Transition -the head of the tribe, according to the expression coined by Manu Leguineche to refer to special envoys and correspondents- represents the value of correspondents in breaking schemes, something that contrasts with

"the strong politicization of the news" in Spain (Haubrich, 2005).

Raphael Minder, current correspondent of The New York Times in Spain, has enumerated some ills of the national press, such as lack of freedom, political polarization, dependence on institutional advertising, and submission to large advertisers (Rivera, 2015). These evils could also be applied to the current Trump administration.

Contrary to what happened during the Spanish Transition, characterized by a very close relationship between foreign correspondents and political power, the situation has changed over the last few legislatures. In a letter sent to the main political authorities just before Rajoy took office as president in December 2011, the Circle of Foreign Correspondents in Spain mentioned that in the seven and a half years of the Zapatero government there were no meetings with the president or with the opposition:

"In the current situation, with the importance of government policies in the context of the European Union crisis, maintaining a channel of communication with the representatives of the international media seems essential to us. We understand that the quality of a democracy also depends on the independence of information professionals, including those of the international media" (Rivera, 2015).

The growing distance between the Government and correspondents has been taking place since 2004, starting with the José Luis Rodríguez Zapatero period as president, and has continued during the legislatures presided over by Mariano Rajoy. Unrest was expressed, for example, when Moncloa's press services made it difficult in 2012 to obtain a physical space for a meeting between foreign correspondents and former judge Baltasar Garzón (Guzmán, 2012). It is, in short, a structural tendency, and not a conjunctural phenomenon linked to a specific cabinet or a specific context, although it has never reached such a level of intensity and protest by foreign correspondents as it did during the independence crisis in Catalonia, between October and December 2017 (Landaluce, 2017).

Contrary to what happened during the Spanish Transition, characterized by a very close relationship between foreign correspondents and political power, the situation has changed over the last few legislatures

\section{Research methodology}

This analysis tries to determine which factors most affect the work of foreign correspondents in Spain from the question of what criteria they consider most influential in their activities.

The Analytic Hierarchy Process (AHP) -a method proposed by Saaty (1980) to deal with complex decisions- offers a rational and comprehensive frame of reference for structuring decision problems. It has also been used, although in a still insignificant way, in social science research (Leyva-Cordero et al., 2007). In short, the AHP is designed to solve decision problems with multiple criteria, where the critical issue is the correct evaluation of the true relative importance of the criteria. For example, when someone is going to buy a car, he/she must take into account various aspects that include price, consumption, safety, aesthetics, and reliability. In order to make a correct decision, that is, to buy the car with the best possible balance of these criteria, it is essential to evaluate the relative importance of these criteria. And there is the value of a method designed to provide something important: to be able to determine, before a set of options, which criteria are really more important and to what extent. This method allows the quantification of preferences and solves the possibility of incorporating intangible and subjective aspects, and the uncertainty inherent in any decision-making process, to the results of a study. 
In the field of Multicriteria decision theory, it has been shown that human beings are highly imprecise when it comes to directly establishing the weight of the criteria that determine a decision, as happens in direct allocation methods. It has been found, for example, that if the questions are repeated in another way or in another order, the decision maker returns completely different weights, which causes a huge distortion in the final decision. To avoid this problem, Saaty developed the AHP method, which is a method of indirect assignment of the values of these weights. Instead of asking the expert or decision-maker directly for the value of the weights of the criteria, a series of structured questions are asked in a much more natural and simple way to answer for a human, through peer-to-peer comparisons and from their answers the weights are calculated by a relatively complex mathematical process. This approach offers two fundamental advantages:

1) The expert assesses the importance of the criteria in a more natural way for the human brain, comparing the importance of the two criteria in two. That is, at all times the expert is only asked to compare the importance (on a predetermined qualitative scale, the scale of Saaty) of one criterion with respect to another, he is never asked for the weight directly and in no case must he have to consider more than two criteria simultaneously. This strategy, which forms the basis of what is known as peer comparison methods, has been shown to be a much more natural and efficient way to establish the relative importance of criteria for a human being. That is, a human being offers much more precise answers when asked if one criterion is more or less important than another, instead of asking directly about the importance of each one. These pairwise comparisons are also made on a scale designed by Saaty, and limited from 1 to 9, where 1 is "equally important" and 9 is "extreme importance", due to the fact that our brain is only able to recognize up to 9 levels of "nuances" in a simultaneous comparison (Saaty, 2006). In short, the AHP method allows us to extract from the expert much more precise weights than those obtained in a direct way, asking in an indirect way, which is much more natural, and making comparisons by pairs of criteria, on an easily understandable scale.

2) This way of obtaining the weights also allows for measuring the inconsistency of the expert when responding. That is, it allows us to reliably measure whether the weights obtained correspond to the expert's opinion on the matter in question, which allows us to substantially reduce the number of experts in the sample. When a traditional survey is used, where those weights are requested directly, the usual strategy to reduce intrinsic imprecision is to use large samples. Since the weights offered directly contain a high distortion, the usual way to reduce it is to average these weights over a large sample, hoping that the mistakes made by some are compensated by the mistakes made by others and, on average, the results are reliable. With the AHP method, on the other hand, we can establish if those weights are accurate, expert to expert, which allows us to verify if the information obtained is reliable using small samples. In this way, a small sample of experts allows obtaining accurate and consistent information, controlling the aggregate precision of the final sample of experts. That is, it allows us to establish the reliability of the information obtained, which in our case is more than $91 \%$, quite high.

In short, the purpose of this method is to quantify human perceptions, limited in rank and numerical values, including a scale of priorities (Moreno-Jiménez, 2002). That is the meaning of the paired comparisons between homogeneous and reduced conglomerates, with short samples, to capture the perceived reality with high precision capacity, as well as to make a good calculation of the priorities and measure the degree of consistency of the interviewee. The panel here is completed by interviews with six experts, in this case correspondents selected by geographical criteria and consistent with the profile of the professional in Spain.

The AHP method allows the quantification of preferences and solves the possibility of incorporating intangible and subjective aspects, and the uncertainty inherent in any decision-making process

According to the geographical profile of correspondents in Spain: Europe (media from 21 countries), America (15 countries), and notably less representative are Asia (6 countries) and Africa (3 countries). There was no correspondent from Oceania. In regards to countries -around 45 with representation- the largest presence of correspondents is from Germany, with 30 media and 36 accredited journalists; United States, 20 media and 48 journalists; and France, 16 media and 22 journalists (Salaverría, 2014). Correspondents were sought to come from these areas, specialize in these areas, or contribute to media in these areas (Guy Hedgecoe writes in Politico, a title of the US based in Europe, and Aïman Zoubir is responsible for Southern Europe -with frequent attention to Maghreb-for Al Jazeera). Also, we tried to represent:

a) the presence of male and female voices;

b) different ages (from Sandrine Morel and Aïman Zoubir, the youngest ones, to Josto Maffeo, the oldest); and

c) testimonies from different work situations (correspondents on staff such as Masako Ishibashi and journalists in autonomous or freelance situations, such as Hedgecoe).

These members made up the panel of journalists. All of them authorized us to use their identities.

- Martin Dahms (Berliner Zeitung, Frankfurter Rundschau).

- Josto Maffeo (II Messaggero, ex).

- Masako Ishibashi (Kyodo News).

- Guy Hedgecoe (Politico, BBC, The Irish Times).

- Sandrine Morel (Le monde).

- Aïman Zoubir (Al Jazeera - South of Europe).

\section{Analysis of the results}

From this point forward, we will analyze the results obtained from the correspondents through the analytic hierarchy process method (AHP) and compare them with those obtained with a standard survey of direct assessment for those same experts and criteria.

Criterion 1: a lack of the Spanish Government collaboration with correspondents (censorship, no invitation to events, 
Table 1. Consistency in correspondents' responses and the relative importance they give to each criterion according to the AHP method (in percentage)

\begin{tabular}{|c|c|c|c|c|c|}
\hline Correspondent & Consistency & $\begin{array}{c}\text { Crit1 } \\
\text { Government collab- } \\
\text { oration }\end{array}$ & $\begin{array}{c}\text { Crit2 } \\
\text { Access to sources }\end{array}$ & $\begin{array}{c}\text { Crit3 } \\
\text { Loss of entity }\end{array}$ & $\begin{array}{c}\text { Crit4 } \\
\text { Spanish sociology }\end{array}$ \\
\hline Aïman Zoubir & 81 & 27 & 61 & 6 & 6 \\
\hline Guy Hedgecoe & 80 & 10 & 50 & 27 & 13 \\
\hline Josto Maffeo & 100 & 25 & 25 & 25 & 25 \\
\hline Martin Dahms & 95 & 38 & 49 & 8 & 5 \\
\hline Masako Ishibashi & 100 & 10 & 10 & 70 & 10 \\
\hline Sandrine Morel & 93 & 24 & 54 & 14 & 8 \\
\hline Average consistence & 91 & 22 & 41 & 25 & 11 \\
\hline \multicolumn{2}{|l|}{ Corrected average } & 23 & 40 & 26 & 11 \\
\hline
\end{tabular}

Notes:

1. For clarity, the percentages have been rounded to the unit.

2. For each correspondent, the most important criterion is marked in bold; the least important one in red.

material impediments, underestimation with respect to national journalists).

Criterion 2: difficulty in accessing sources (existence of channels with opaque inertias, without transparency mechanisms, characterized by distrust).

Criterion 3: setting of the agenda due to the loss of correspondents' status (lack of human and material resources, extension of schedules, extension of work with multimedia tasks).

Criterion 4: clash with Spanish culture (closed culture, aversion to foreigners, customs incompatible with the work of correspondents, weight of the topical image of Spain in their own environment).

Table 1 shows the relative importance that each of the correspondents grants to each of the criteria through the AHP method.

As indicated above, one of the great advantages of the AHP method is the ability to measure the consistency in the answers of the respondent, which allows us to estimate if he/she has a clear and defined knowledge on the subject in question or, on the contrary, he/she tends to wander or lacks a well-defined opinion. In this case, in column 2 of Table 1 , we find the value of the consistency obtained for each of the respondents. It can be seen that all reach a minimum of $80 \%$ and that the average consistency is $91 \%$, which allows us to conclude that the panel of experts chosen has a clear and well-formed opinion on the subject and leads us to consider that the values analyzed below are valid.

These values, with the relative importance of each one of the criteria, can be found in columns 3 to 6 of Table 1 . In bold we find the most important criterion for that correspondent highlighted and in red the least important. First, it can be seen that for 4 of the 6 correspondents the most important is criterion 2 (the difficulty in accessing the sources, which is $41 \%)$. For a fifth correspondent, it is a criterion that is as important as the others. Criterion 3 and criterion 1 (decrease in the entity of correspondents and lack of government collaboration, respectively) are next in importance, although at a clear distance from the first. Both present a very similar joint assessment (25\% and $22 \%$ ).
On the other hand, for 5 of the 6 correspondents, the least important criterion is 4 (conditions of Spanish sociology, $11 \%)$. In short, correspondents understand that access to sources is what most hinders their task, more so than the lack of resources, time, status of the correspondents (loss of entity), or lack of government collaboration. Of all the criteria taken into account, the particularities of the Spanish culture and society are those that have only a minor impact on the work of the journalists studied.

What has a greater negative weight for the correspondents is access to sources, and when they begin to describe obstacles of the Government, their argument ultimately leads to the inaccessibility of the sources

We note that there are two very different opinions in the sample: Masako Ishibashi, which considers criterion 3 (decrease in the entity of the correspondents) the most important, and Josto Maffeo, who estimates that there is no difference in importance between any of the criteria. To analyze graphically the similarities and differences between the correspondents, a principal component analysis (PCA) was conducted, a statistical technique that allows us to reduce the dimensionality of a set of observations. The PCA consists of a linear transformation that determines a new coordinate system for the original data set. In this new coordinate system the variance of the largest size of the data set is captured on the first axis (called: first principal component), the second largest variance is the second axis, and so on. We have focused on the first two components to obtain a two-dimensional graphic: Graph 1 contains $88 \%$ of the total information, thus offering a reduced distortion.

The graph shows how the responses of the other four correspondents are quite homogeneous. They agree that criterion 2 (difficulty in accessing the sources) as the most important, although for Aïman Zoubir, Martin Dahms, and Sandrine Morel the second most important criterion is 1 


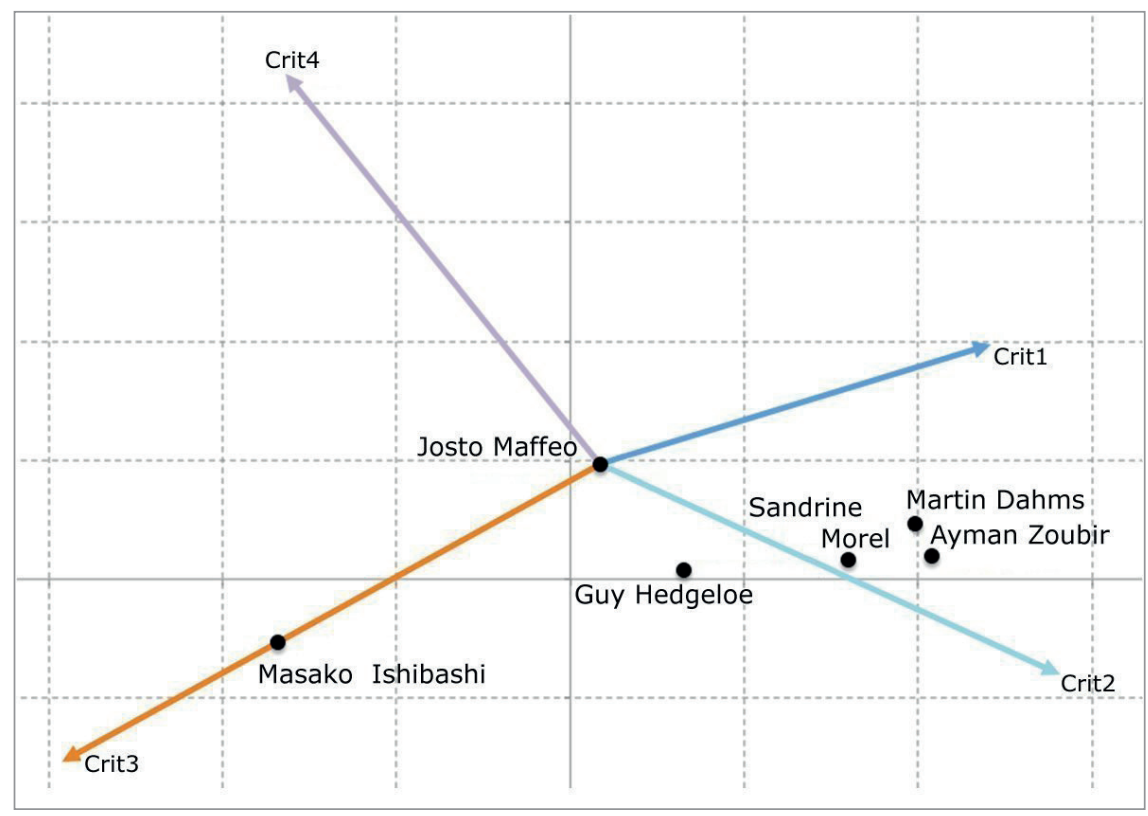

Graph 1. PCA for the results of the survey, showing the disparity of opinions

most difficult task is dealing with the government (censorship, lack of treatment, underestimation with regard to Spanish journalists...) but in fact getting statements or clarification from sources is the most difficult, be they governmental, political parties, companies or other public or private institutions.

In the follow-up interviews conducted during the fieldwork this conclusion was confirmed: greater negative weight for the correspondents is access to sources, and when they begin to describe obstacles of the Government, their argument ultimately leads to the inaccessibility of the sources. It is interesting to note how the importance of criterion 1 is reduced, which, however, is the most referred in direct assessments. Martin Dahms does not perceive a lack

(lack of government collaboration), while for Hedgecoe it is 3 (decrease of the social status of the correspondents).

After conducting personal interviews with each correspondent with open questions, but focusing on the four criteria, the same panel was asked to assess such criteria directly, that is, as in a traditional survey, scoring from 0 to 10 each one's importance. From these absolute valuations, Table 2 shows the relative importance granted to each criterion by each correspondent.

Table 2 shows results clearly different from those of the AHP method. In this case, the most important criterion does not turn out to be 2 (difficulty in accessing sources) but 1 (lack of government collaboration), which becomes the most important criterion for 4 of the 6 correspondents (and as a criterion as important as the others for a fifth correspondent). That is, the greatest importance has shifted from criterion 2 to 1 , so that different conclusions would be obtained. The obvious question would be which of the two measures is more reliable.

AHP solves the answer to that question because it also provides a measure of consistency for each one of the participants in the panel, in this case the group of correspondents with an average of more than $90 \%$. In the case of a direct valuation method, from 0 to 10 , there is no way to measure this consistency of answers. Therefore, we can conclude that there are reasons to trust the first table and not the second. In this case, a direct valuation method would have offered a distorted image, as has been noted. Correspondents may perceive it that way (the government as the main "obstacle"), but the consistency analysis provided by AHP says otherwise. In fact, this is what usually happens: someone might think that a foreign correspondent
Table 2. Relative importance of the criteria through direct valuation of the correspondents (percentages)

\begin{tabular}{|l|c|c|c|c|}
\cline { 2 - 5 } \multicolumn{1}{c|}{} & $\begin{array}{c}\text { Crit1 } \\
\text { Government } \\
\text { collaboration }\end{array}$ & $\begin{array}{c}\text { Crit2 } \\
\text { Access to } \\
\text { sources }\end{array}$ & $\begin{array}{c}\text { Crit3 } \\
\text { Loss of } \\
\text { entity }\end{array}$ & $\begin{array}{c}\text { Crit4 } \\
\text { Spanish } \\
\text { sociology }\end{array}$ \\
\hline Aïman Zoubir & $\mathbf{4 4}$ & 44 & 6 & 6 \\
\hline Guy Hedgecoe & $\mathbf{3 6}$ & 23 & 18 & 23 \\
\hline Josto Maffeo & $\mathbf{2 5}$ & 25 & 25 & 25 \\
\hline Martin Dahms & $\mathbf{3 8}$ & 25 & 25 & 13 \\
\hline Masako Ishibashi & 20 & 20 & 50 & 10 \\
\hline Sandrine Morel & $\mathbf{4 0}$ & 40 & 13 & 7 \\
\hline Direct valuation & 34 & 29 & 23 & 14 \\
\hline
\end{tabular}

Notes:

1. For clarity, the percentages have been rounded to the unit.

2. For each correspondent, the most important criterion is marked in bold; the least important one in red. 
Spain has lost weight at the level of international information or from previous experiences that have led us to the conclusion that useless effort leads to melancholy."

Guy Hedgecoe is also critical of the Government of Rajoy:

"He has collaborated little. He is not very interested in maintaining contact with the foreign press. Of course l've tried to get interviews with Rajoy. Of course it will be difficult to get an interview with the President of the Government of any country. But here it has been impossible. And it's not just with foreigners. It's with the press in general."

The relative consistency of these comments does not justify criterion 1 being dominant in determining the problems correspondents face. On the contrary, more than the collaboration of the Government, these problems are related to the sources, which was criterion 2, as it emerged from the AHP analysis. Martin Dahms states in the interview:

"The role of politics in general is overestimated. Maybe for any correspondent, but more for my role as a correspondent in Spain, we must think that what we do here is to write about Spain, but not about Spanish politics. Obviously, you need the Government, but I do not specifically need government support. I need the same thing that Spanish colleagues need. Sometimes the government should be the best source for certain data and numbers and figures. I had more problems before the internet because I suddenly needed to call to know these numbers. I always remember a call about the number of murders that had occurred in Spain to the Ministry of the Interior. The answer is 'We cannot know that'. And who can know if it is not the Ministry of the Interior? Evidently, that type of information, now you find it on the Internet, and on the Government's own pages. But I have not encountered political obstacles."

The difficulty to access the sources should not be understood as an expression of a sociological singularity. Rather, it responds to a structural motive that emanates from a deficit of democratic culture in the governing system

Sandrine Morel refers to the heads of the press and the filters of those responsible for communication, whose attitudes are highlighted as a problem, and emerges in coherence with the analysis:

"This is terrible for our work because it forces us to repeat the press releases and official appointments without being able to ask and cross-examine the Secretaries of State in this case, which is often the people to ask when there are specific issues."

For his part, Aïman Zoubir emphasizes that

"there is a structural problem and lack of maneuverability. In France a director of an outdoor area can grant an interview or participate in a live program, in Spain that is currently unthinkable."

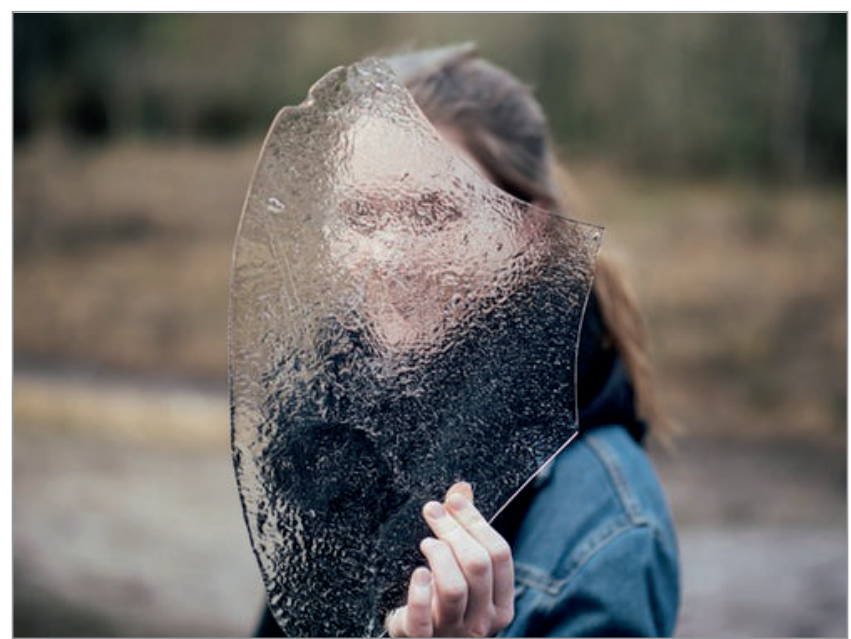

.sometimes it's that the source wants to be anonymous. Photo: https://unsplash.com

The overuse of the off in Spain is also emphasized by Sandrine Morel:

"The problem sometimes is not that you do not have access to the source, it's that the source wants to be anonymous. And that is another more serious problem because in your articles it seems that you invent things, and nobody can really know what your source is, if he is a critic within the government, if he is a representative of a majority current, if it is a credible source, or with harmful interests behind that you do not know. And this is true. In Spain there is a serious problem that is that this has become the rule. And to get an information in on is very complicated. This for governments is like that, for institutions it depends."

Even Masako Ishibashi, who maintains a low critical tone, admits the occasional difficulty of accessing the sources. Hedgecoe, more than opacity, presents an added problem, and it is the hierarchy:

"What is more frustrating is how to get information from a medium with less public, with less popularity."

Veteran Josto Maffeo in effect refers to the problem of government collaboration and mentions

"the parties and the businessmen... the social strates in general. Each one has his political calculation and at a certain moment they may be interested in not giving the information, and they have every right not to give it. Another thing is that they do not give you a piece of information that has to be public, that's different. But sometimes it's not that they are hiding it, it's simply that the mechanism is cumbersome."

The problem of access to institutional sources is relevant because, as most research shows, there is a preference of the information professional by traditional or official sources, compared to alternative sources such as social media, since writing from official sources endows the journalist's work with superior credibility (Westerman; Spence; Vander-Heide, 2014). 


\section{Conclusions}

1. The method of the hierarchical analytical process (AHP), which has been used infrequently in the journalism discipline, is effective in reducing the uncertainties inherent in communication studies with multicriteria issues. This analysis of foreign correspondents confirms that answers given in an interview or in a direct assessment are clarified through this corrective method. The hierarchical model through paired comparisons using the fundamental scale provides optimal results.

2. Although there is a recurrent mention, the loss of status of correspondent agencies (less human and material resources, more multimedia tasks, extended hours, etc.), the journalists who work in them seem to have assumed the changes and do not consider them the main obstacle in the accomplishment of their tasks.

3. The difficulty of accessing the sources appears to be the factor of greatest hindrance to the professional activity of the foreign correspondents analyzed, whose limited number is precisely what justifies the use of the AHP to give them representative value when calibrating the consistency. In Spain, the main problem shown by the journalists included in the panel is not that the Government does not cooperate with the correspondents. This collaboration, as stated in the study, exists, but stops before a generalized barrier such as the brake on access to sources. This barrier is mentioned both within the government and outside it (in companies, institutions, etc.) and can be derived from a political decision (that the president does not grant interviews) but also from an excess of prudence (press officers who do not allow the journalist to connect with sources, sources that declare off the record, etc.). It should be said that even when the correspondents refer to obstacles on the part of the government, they are in many cases referring to their difficulties with the sources within it.

4. The difficulty to access the sources should not be understood as an expression of a sociological singularity, a factor that is the most irrelevant of all those considered. Rather, it responds to a structural motive that emanates from a deficit of democratic culture in the governing system. Hence the abuse of anonymity, contrary to the ethical demands of the profession, or of spokespersons behind which to hide to make direct verbal manifestations of relevant figures difficult for journalists.

5. The value accorded to sources, and in particular to official sources, is consistent with the investigations that reaffirm the role of the journalist in the face of the competition generated by citizen journalism and social media, revealing some resistance of professionals to accept these as informative sources (Martín; Gómez-Nadal, 2016).

6. Due to its relevance and silent negative effect (abundance of off the record), we believe the difficulties encountered by foreign correspondents in Spain, with respect to sources, are sufficiently striking and should be subject to further analysis in the field of communication. If it has traditionally been considered that correspondents have a tendency to consult elite sources - which could lead in some cases to a biased view of the world and a partial or privileged account of the reality of the countries-, now that the elite, political or not, could be getting used to the anonymous expression, which would be a detriment to the understanding that citizens have of the events. More extensive investigations are needed to delve into the important issue that emerges in this detailed study.

7. In the investigation it was observed that the correspondents would like more pleasant relations with the sources of the Government. This idea poses a conflict with the basic objective of journalism of control and research of power. A too close relationship between a correspondent and a government source makes it difficult for the journalist to maintain an adequate distance, avoiding a relationship that is too cordial to report rigorously and as closely as possible to an objective viewpoint (Herman; Chomsksy, 1988). The concept of "information grants" reminds how entities interested in appearing in the media can provide such resources and services "ready to use" -press releases, seminars, conferences- in order to achieve prominence and indirectly controling journalistic works (Gandy, 1982). The Cardiff University's research "A compromised fourth state? UK news journalism, public relations and news sources" shows the weight that materials provided by public relations teams have had in journalistic content (Lewis; Williams; Franklin, 2008).

\section{Acknowledgments}

This publication has been financed with funds from Departamento de Periodismo of Universidad de Málaga.

\section{References}

Archetti, Cristina (2012). "Which future for foreign correspondence? London foreign correspondents in the age of global media". Journalism studies, v. 13, n. 5-6, pp. 847-856. https://doi.org/10.1080/1461670X.2012.664352

Belair-Gagnon, Valerie; Agur, Colin; Frisch, Nicholas (2016). "How foreign correspondents use chat apps to cover political unrest". Columbia journalism review, 6 Nov. http://www.cjr.org/tow_center_reports/foreign_ correspondents_chat_apps_unrest.php

Círculo de Corresponsales Extranjeros en España (2011). Carta al futuro presidente del Gobierno, Mariano Rajoy, y al resto de partidos políticos.

https://web.archive.org/web/20160415043403/http:/ corresponsales.com/files/pdf/CartaRajoy.pdf

Galtung, Johan (2014). “Foreign correspondence 50 years later". In: Terzis, George (ed.). Mapping foreign correspondence in Europe. London: Routledge, pp XVII-XXI [preface]. ISBN: 9780415719001

Gandy, Oscar H. (1982). Beyond agenda setting: information subsidies and public policy. New Jersey: Norwood. ISBN: 9780893910969

Guzmán, Cecilia (2012). "Presidencia veta un encuentro de los corresponsales extranjeros con Garzón”. Elplural.com, 1 septiembre.

https://goo.gl/9KfdqA 
Hamelink, Cees (2014). "Epilogue". Mapping foreign correspondence in Europe. London: Routledge, pp. 314-318. ISBN: 9780415719001

Haubrich, Walter (2005). "Corresponsales en España. Tres preguntas sobre la profesión y los medios". En: Farias, Pedro (dir.). Informe anual de la profesión periodística, 2005. Madrid: APM, pp. 61-67. ISBN: 8487641237

http://www.apmadrid.es/wp-content/uploads/2009/02/ Informe\%20APM\%202005.pdf

Herman, Edward; Chomsky, Noam (1988). Manufacturing consent: The political economy of the mass media. New York: Pantheon Books. ISBN: 9780375714498

Landaluce, Emilia (2017). "La crítica de los corresponsales extranjeros: 'Moncloa sólo nos convoca para hablar de los Reyes Católicos'". El mundo, 21 octubre.

https://goo.gl/D4VrSA

Leyva-Cordero, Oswaldo; Reyna Zambrano, Virginia-Esther; Arango-Morales, Xóchitl; Cuevas-Pérez, Verónica-Ascensión; Tamez-González, Gerardo (2013). “Propuesta de un catálogo de competencias docentes en la Facultad de Ciencias Políticas y Administración Pública de la UANL, a través del método: proceso de análisis jerárquico (AHP)". Revista iberoamericana para la investigación y el desarrollo educativo, v. 10, n. 1, pp. 1-21.

http://eprints.uanl.mx/6160

Lewis, Justin; Williams, Andrew; Franklin, Bob (2008). The quality and independence of British journalism: Tracking the changes over 20 years. Cardiff: Cardiff University, pp. 13-29. https://orca.cf.ac.uk/18439/1/Quality\%20\%26\%20 Independence\%20of\%20British\%20Journalism.pdf

Martín, Elena; Gómez-Nadal, Mariona (2016). “Los medios sociales como fuente de información para corresponsales en el extranjero. Aproximación al estado de la cuestión". Comunicació: Revista de recerca i d'anàlisi, v. 33, n. 1, pp. 119-137.

https://doi.org/10.2436/20.3008.01.145

Moreno-Jiménez, José-María (2002). “El proceso analítico jerárquico (AHP). Fundamentos, metodología y aplicaciones". Recta, primer semestre, n. 1, pp. 21-53.

https://goo.gl/jeofU8

Nieman Foundation (2010). Reporting from faraway places. Who does it and how? Harvard: Harvard University; The Nieman Foundation. Nieman reports, v. 64, n. 3.

http://1e9svy22oh333mryr83/4s02.wpengine.netdna-cdn. com/wp-content/uploads/2014/03/fall2010.pdf
Redondo-Escudero, Myriam (2005). Internet como fuente de información en el periodismo internacional. Tesis doctoral. Universidad Complutense de Madrid.

https://internetcomofuente.wordpress.com

Redondo-Escudero, Myriam (2007). "Cambiar de canal no es cambiar de fuente. El cauteloso acercamiento de los corresponsales a internet". Razón y palabra, n. 59, 24 de febrero.

http://www.razonypalabra.org.mx/anteriores/n59/varia/ mredondo.html

Rivera-Hernández, Agustín (2015). "Últimas noticias de los corresponsales extranjeros en el España". Cuadernos de periodistas, 24 noviembre.

http://www.cuadernosdeperiodistas.com/ultimas-noticiasde-los-corresponsales-extranjeros-en-espana

Saaty, Thomas (1980). The analytic hierarchy process: Planning, priority setting, resource allocation. New York: McGraw-Hill, pp 10-25. ISBN: 9780070543713

Saaty, Thomas (2006). "The analytic network process". In: Saaty, Thomas; Vargas, Luis. Decision making with the analytic network process. Economic, political, social and technological applications with benefits, opportunities, costs and risks. New York: Springer, pp. 1- 26. ISBN: 9780387338590

Sahagún, Felipe (2004). “Corresponsales de guerra, de la paloma a internet". Cuadernos de periodistas, n. 0.

http://www.cuadernosdeperiodistas.com/pdf/Cuadernos_ de_Periodistas_0.pdf

Sahagún, Felipe (2013). "Corresponsales extranjeros, ¿̇especie en extinción o en transformación?". Cuadernos de periodistas, 12 julio.

http://www.cuadernosdeperiodistas.com/corresponsalesextranjeros

Salaverría, Ramón (2014). "Foreign correspondents in Spain: Facing the economic and professional crisis". En: Terzis, Georgios (ed.). Mapping foreign correspondence in Europe. London: Routledge, pp. 243-251. ISBN: 9780415719001

Sambrook, Richard (2010). Are foreign correspondents redundant? The changing face of international news. Oxford: Reuters Institute for the Study of Journalism, pp. 59-65. ISBN: 9781907384004

Westerman, David; Spence, Patric; Van-der-Heide, Brandon (2014). "Social media as information source: Recency of updates and credibility of information". Journal of computer-mediated communication, v. 19, n. 2, pp. 171-183.

https://doi.org/10.1111/jcc4.12041 